\title{
A study on the effect of motor development support program conducted on 36-47 month children and mothers on the motor development of children*
}

\author{
36-47 aylık çocuklara ve annelere uygulanan motor gelişim destek \\ programının çocukların motor gelişimine etkisinin incelenmesi
}

\author{
Taşkın Taştepe ${ }^{1}$, Aysel Köksal Akyol ${ }^{2}$
}

Article History

Received : 11 June 2020

Revised : 25 August 2020

Accepted : 18 November 2020

Article Type

Research Article

\begin{abstract}
The purpose of this study is to determine the effect of the motor development support programs conducted on 36-47 month-old children and mothers with children of this age group on motor development of children and to compare the effects of the program conducted on the children and the program conducted on the the mothers. The sample group of the study consisted of 13 children of 3643 months (experimental group-I), 10 mothers with 36-43 month-old children (experimental group-II) and 12 children of 36-43 months (control group). The data were collected by means of using the Peabody Developmental Motor Scales-2. Experimental group-I was applied the motor development support program for children (MDSP-C) while experimental group-II was applied the motor development support program for mothers (MDSP-M). As a result of the study, it was determined that the score increase in both the stationary subtest and gross motor quotient of the children was caused by the motor development support programs (MDSP-C \& MDSP-M), yet the experimental procedures did not provide any advantages compared to each other. It was also determined that neither MDSP-C nor MDSP-M had any effects in increasing the locomotion, object manipulation, grasping, visual-motor integration and fine motor scores of the children.
\end{abstract}

Keywords: Motor development support program, Gross motor, Fine motor, Preschool

Öz: Bu araştırmanın amacı, 36-47 aylık çocuklara ve bu yaş grubu çocuğa sahip annelere uygulanan motor gelişim destek programlarının çocukların motor gelişimine etkisini belirlemek ve çocuklara uygulanan program ile annelere uygulanan programın etkilerini karşılaştırmaktır. Araştırmanın çalışma grubunda 36-43 aylık 13 çocuk (deney I grubu), 36-43 aylık çocuğa sahip 10 anne (deney II grubu) ve 36-43 aylık 12 çocuk (kontrol grubu) yer almaktadır. Veriler, Peabody Motor Gelişim Ölçeği-2 kullanılarak toplanmıştır. Deney I grubuna çocuklar için motor gelişim destek programı (Ç-MOGDEP), deney II grubuna anneler için motor gelişim destek programı (A-MOGDEP) uygulanmıştır. Araştırmada sonuç olarak; çocukların hem denge alt boyutunda hem de kaba motor boyutunda meydana gelen puan artışının motor gelișim destek programlarından (C-MOGDEP \& A-MOGDEP) kaynaklandığı ancak deneysel işlemlerin birbirine göre herhangi bir avantaj sağlamadığı tespit edilmiştir. Ayrıca Ç-MOGDEP ile A-MOGDEP'in çocukların yer değiştirme, nesne yönlendirme, kavrama, el-göz koordinasyonu ve ince motor puanlarını artırmada herhangi bir etkiye sahip olmadığı belirlenmiştir.

Anahtar Kelimeler: Motor gelişim destek programı, Kaba motor, İnce motor, Okul öncesi

\footnotetext{
${ }^{*}$ This article was written based on the doctoral dissertation by the first author.

Corresponding Author: Taşkın Taştepe

Ankara University, Faculty of Health Sciences, Department of Child Development, e-mail:ttastepe@ankara.edu.tr, ORCID: https://orcid.org/0000-0003-2603-4041

2 Ankara University, Faculty of Health Sciences, Department of Child Development, e-mail:ayselkoksalakyol@ankara.edu.tr, ORCID: https://orcid.org/0000-0002-1500-2960
} 


\section{INTRODUCTION}

Although children do not remain dependent to their parents through motor skills that develop with age, parents should still support their children's motor actions based on their developmental stages. Attitudes of parents towards their children play a key role in regards to the development of their children (Temel \& Kurtulmuş, 2016). For the motor skills exhibited by children, parents increase the quality and repetition frequency of the skills by supporting and encouraging their children (Caulfield, 2000). However, the fact that parents do not have enough knowledge about their children's development reflects negatively in the child's development and education. In the study conducted by Büyüktaşkapu (2012) with mothers of children aged between 1-3 years, it was determined that the majority of children were inadequate in fine motor development and more than half of them were inadequate in gross motor development. On the other hand, the study conducted by Haktanır and Aktaş (1995) to investigate the motor development characteristics of 3-4 year-old children showed that since the majority of families do not know the level of development required by the age of the children, they do not know whether children need developmental support or not. Another study conducted by Silya, Flôres, Corrêa, Cordovil, and Copetti (2017) argued that mothers with children of 16-66 months considered their children's motor competence superior to their children's performance. In their research evaluation where the household video recordings of mothers with children of 0-19 months were examined in relevance to the motor development process, Boonzaaijer, van Wesel, Nuysink, Volman, and Jongmans (2019) concluded that the counseling services and feedback that the relevant mothers were given increased their knowledge and awareness towards the motor development process of their children. The fact that the house is a lifelong learning environment is emphasized and the importance of creating appropriate environment for children is underlined in studies which show the effect of the stimuli that is provided within the house on children's motor development (Valadi \& Gabbard, 2020). The study conducted by Kavousipor et al. (2020) showed that the daily household activities had a significant effect on 3-18 month old children's fine and gross motor skills. The same study also reflected the fact that the stimuli provided by the parents in the first year of life has a determinant effect on the motor development process. Each of these studies agreed that parents should have the required knowledge and skills to support their children's motor development.

When 3 to 6-year old preschool children with unemployed mothers are taken into considertion, the primary responsibility of supporting the development and education of children belongs to the mother. In order to inform mothers about the development of their children and how to support their motor development, the development and implementation of motor development support 
programs should be provided. Establishing appropriate support programs for the child is important for monitoring motor development and identifying usual or unusual motor skills (Haywood, Roberton, \& Getchell, 2012). Hürmeriç Altunsöz (2015), states that the majority of children between the ages of 3-6 are inadequate in terms of motor development and adds that the motor skill applications offered to support the inadequacies in children's motor development are generally effective in her study, which compiles motor skill applications by reviewing the literature. In addition, it has been concluded in the literature that motor development support (intervention) programs such as fine motor education program (Kalıpçı Söyler, 2019), hand-eye coordination and body exercise based education program (Oi, Tan, Sui, \& Wang, 2018), psychomotor program (Anna, Glykeria-Erato, Aspasia, \& Fotini, 2016), physical activity program (Vidoni, Lorenz, \& Terson de Paleville, 2014) and basic movement education program (Boz \& Güngör Aytar, 2012) conducted on children between the ages of 3-6 support gross/fine motor development of children. Programs were conducted only on children in relevant studies. In various studies involving parents in the intervention process to support children's motor development, children's object control skills were focused (Hamilton, Goodway, \& Haubenstricker, 1999; Hurmeric, 2010). Having said that, it is noteworthy that in motor development support programs that support both gross and fine motor development of children, children and mothers are not included together.

In line with all this information, in order to support the motor development of the child, applications appropriate to the age and developmental characteristics that can meet individual needs should be provided to the child and the mother providing basic care to the child. In this study, it is aimed to determine the effect of motor development support programs conducted on 36-47 month-old children and the mothers with children in this age group on the motor development of children and to compare the effects of the program conducted on the children and the one conducted on the mothers. Therefore, the fact that the motor development support programs prepared for the children and mothers will support the gross and fine motor development of children together through play-based activities allows this study to differentiate from other reviewed studies. In accordance with the purpose of the study, the following questions were sought to answer:

1. What is the effect of motor development support program conducted on 36-47 month-old children on their motor development?

2. What is the effect of motor development support program conducted on mothers with 3647 month-old children on children's motor development? 
3. Is the effect of motor development support program conducted on 36-47 month-old children on their motor development permanent?

4. Is the effect of motor development support program conducted on mothers with 36-47 month-old children on children's motor development permanent?

\section{METHOD}

\section{Research Design}

In the research, quasi-experimental design with pretest, posttest and retention test is used in order to identify the effects of motor development support programs, developed for 36-47 month-old children and mothers with children in this age group, on children's motor development. Dependent variable of the study is "motor development skills" of 36-47 month-old children while independent variables are programs developed in order to support children's motor development; "Motor Development Support Program for Children (MDSP-C)" and "Motor Development Support Program for Mothers (MDSP-M)".

\section{Study Group}

The population of the study was composed of 36-47 month-old children attending public preschools in central districts of Ankara in 2017-2018 academic year and the mothers who had children in this age group. In order to form the sample group, a list of public preschools in central districts was obtained from the Ankara Provincial Directorate of National Education and interviews were conducted with school principals, but it was found out that in some preschools, classes with 36 months old children were not opened. This situation was justified by the letter numbered 28219185-100-E.5156905 and dated 14.04.2017 of the General Directorate of Basic Education of the Ministry of National Education. In the letter, it is stated that in order to ensure $100 \%$ schooling of 54 months and over children starting from the 2017-2018 academic year, it is not necessary to open an optional class in preschools for younger children without meeting the educational needs of this age group. In this respect, preschools with similarities in terms of social, cultural and economic characteristics were identified in order to form equivalent groups among the preschools having classes for the age of three. Three preschools in the same district with these criteria were selected in accordance with the necessary permissions. Two schools were assigned to experimental group-I including 36-47 month-old children and experimental group-II including the mothers of children in this age group. The other school represents the control group including 3647 month-old children. The physical conditions of the schools were taken into consideration while 
determining the groups. A school with both indoor and outdoor facilities was chosen fort he applications to be carried out with the children in experimental group-I while a school that will also enable meetings was chosen for the applications to be carried out with the mothers in experimental group-II. The school that did not provide the appropriate physical conditions was chosen as the control group.

It was determined that the school of experimental group-I had one 3-year-old classroom ( $\mathrm{n}=18)$, the school of experimental group-II had two 3-year-old classrooms $\left(\mathrm{n}_{1}=19, \mathrm{n}_{2}=19\right)$ and the school of the control group had one 3-year-old $(n=18)$ classtoom and the class lists were provided. The children of 36-43 month* chronological age were determined among the lists before the applications started. While determining experimental group-I and control group 15 parents of 3643 month-old children for each group were discussed with while 34 parents of 36-43 month-old children were discussed with and the necessary information about the study was explained. Upon the consent of the families, 13 children formed experimental group-I, 13 children formed the control group and 13 mothers that agreed to take part in the study formed experimental group-II. Each student in experimental group-I took part in the study process. The pretests of the children whose mothers were included in experimental group-II were carried out, yet one of the relevant mothers stopped participating the sessions after the first one while two mothers that declared thir participation in the study never showed up. The children in the control group took the pre-test, yet one child was not given the posttest due to sickness absence. Therefore, one child was taken out of the study.

Having said that, there were 13 children ( 7 girls and 6 boys) at the age of 36-43 month-old in experimental group-I, 10 mothers (mother of 6 girls and 4 boys) with 36-43 month-old children in experimental group-II and 12 children (7 girls and 5 boys) at the age of 36-43 month-old in the control group. $20(57.1 \%)$ of the children were girls and $15(42.9 \%)$ were boys and the mean age of the children was 39.6 months $(\mathrm{SD}=2.24)$. It was determined that $31(88.6 \%)$ of the children did not attend preschool education institutions and 4 (11.4\%) children who attended preschool education institutions benefited from preschool education for less than one year. The mean age of

\footnotetext{
* The main reason for considering the 36-43 month-old children is that 43 month-old children at upper limit of this age range would be 47 months old due to periods of pretest, experimental procedure, posttest, and retention test since the adaptation study of the scale to be used to evaluate motor development of the children was conducted for 36-47 month-old children.
} 
the mothers who participated in the study as experimental group-II was 35.6 ( $\mathrm{SD}=5.06)$. When the educational status of the mothers was examined, it was found out that 1 of the mothers had secondary school, 4 had high school, 4 had bachelor's and 1 had master's degree. None of the children attended any kinds of course that would effect their motor development process. Likewise, mothers in experimental group-II did not receive any education.

Children in experimental group-I continued their education in accordance with the Turkish Ministry of National Education (2013a) national preschool education program during when MDSP-C was not conducted. Likewise, the children of the mothers who took part in experimental group-II that MDSP-M was conducted and the children in the control group where the motor development program was not conducted continued their education in accordance with the Turkish Ministry of National Education (2013a) national preschool education program.

In experimental group-I that was conducted the MDSP-C, although pretests, posttests and retention tests were given to the students of 36-43 month, children older than 43 months were not discriminated with the principle of equality in education and they were made to benefit from MDSP-C as well. After experimental process was completed, MDSP-C was shared with the teacher of the children in control group and information about the study was explained. Thus, children in the control group were also made to benefit from the program.

\section{Data Collection Tool}

Peabody Developmental Motor Scales-2 (PDMS-2) developed by Folio and Fewell (2000) to determine the motor development levels of children from birth up to 71 months was used as the data collection tool in the study. PDMS-2 can be used for both children with age-expected development and children with special needs. PDMS-2 is composed of two quotients as gross and fine motor and six subtests as reflexes, stationary, locomotion, object manipulation, grasping and visual-motor integration. Gross motor quotient is the combination of reflexes ${ }^{* *}$, stationary, locomotion and object manipulation subtests measuring the use of large muscular systems; whereas, fine motor quotient is a combination of the results of grasping and visual-motor integration subtests that measure the use of small muscular systems (Folio \& Fewell, 2000). The

\footnotetext{
** Since the reflexes give place to volitional acts with the help of the maturation of nervous system when the child is 12 month-old, reflexes subtest is applied to children who are between 0 and 11 month-old. Therefore, reflexes subtest is not included in this study.
} 
fact that PDMS-2 evaluates both gross and fine motor development of children in detail from birth to primary school has been an effective data collection tool in this study.

While scoring the PDMS-2, each item is based on 2, 1, 0 points. 2 points for an item show that the child performs the item according to the criteria specified for mastery while 1 point shows that the child's performance has a clear resemblence to the criteria specified for mastery yet still lacks to meet it fully, and 0 points show that the child does not attemp to meet the item or fails to meet the item according to the criteria specified for mastery. Applicant rating scale starts with the item of entry point according to the age of the child. If the child scores 0 or 1 point from any of the first three item from the beginning, they are retrospectively tested until they score 2 points in three successive items and the basal level is set. All the items below the basal level are scored as 2 points. After setting the basal level, the ceiling level is set when the child scores 0 points in three successive items and the scale is finalized. Following this, each item is scored as 0 points (Folio \& Fewell, 2000). In this way, raw scores are obtained.

The adaptation study of PDMS-2 for Turkish children was conducted by Taştepe and Köksal Akyol (2019). In the adaptation study, the content validity based on expert opinions, confirmatory factor analysis to collect evidence for construct validity, $\mathrm{Cr}-\alpha$ coefficient for determining the reliability and test-retest coefficient by applying the scale approximately two weeks after the first application to increase the evidence for reliability were examined. The content validity of PDMS-2 was found to be statistically significant. As a result of the confirmatory factor analysis $\left[\chi^{2}=7.48\right.$; $d f=4$; $\chi^{2} / \mathrm{df}=1.87$; RMSEA=.068; GFI=.98; AGFI=.94; NFI=.98; NNFI=.98; CFI=.99; $\left.\mathrm{SRMR}=.027\right]$, PDMS-2 was determined to be confirmed by the gross and fine motor quotients and the subtests of these quotients. It was concluded that $\mathrm{Cr}-\alpha$ internal consistency coefficient varied between .76 and .88 for the subtests and was .91 for gross motor quotient and .88 for fine motor quotient. Testretest reliability coefficient was determined to vary between .96 and .99 for the quotients/subtests. The obtained results showed that PDMS-2 can be used as a valid and reliable measurement tool for Turkish children.

\section{Creation of Motor Development Support Program for Children (MDSP-C)}

MDSP-C is a training program applied to experimental group-I to support the motor development of 36-47 month-old children. The program is based on supporting the families by means of family involvement studies conducted both to center the children continuing to preschool education institution and benefiting from education and to support the child's development at home. In this respect, it represents an insight to Bronfenbrenner's bioecological systems theory that emphasizes 
the speculative extend of the program and the relationship between the institution (school) and the house (Bronfenbrenner \& Morris, 2006).

MDSP-C is a unique program written by the researcher. Having a a play-based structure, the program consists of a total of 24 activities to be applied twice a week for 12 weeks. The duration of each activity is planned to be 20-30 minutes. The play-based activities included in the program were prepared by taking into account the sub-dimensions of PDMS-2 (stationary, locomotion, object manipulation, grasping, visual-motor integration) and the motor development characteristics of the 36-47 month-old children in the PDMS-2 motor development chart. Having said that, the activities were formed according to the motor development objectives and indicators since the focus of the research was on the gross and fine motor skills of the children. The acquisitons and indicaters of the activities in MDSP-C have been set by taking Turkish Ministry of National Education (2013a) national preschool education program into consideration and the activities have been created according to the activity plan format included in the mentioned national program. Since the learning processes of the activities were prepared by using different types of activities (language, literacy, mathematics, music), children's motor development as well as other areas of development was indirectly supported. The activities in the program are presented in Table 1.

Table 1. MDSP-C activities

\begin{tabular}{|c|c|c|c|c|}
\hline Week & $\mathrm{Nar}$ & he of the Activity & Motor Development Area & Movement Skills \\
\hline \multirow{2}{*}{1} & 1 & Let's Meet and Play & $\mathrm{L}-\mathrm{VMI}$ & \multirow{2}{*}{ - } \\
\hline & 2 & String Puppet Says & $S-L$ & \\
\hline \multirow{3}{*}{2} & 3 & How the Stork Moves & $S-G$ & \multirow{3}{*}{$\begin{array}{l}\text { Standing on one foot } \\
\text { Standing on tiptoes } \\
\text { Imitating the movements }\end{array}$} \\
\hline & & & & \\
\hline & 4 & Moving Ribbon & $\mathrm{S}-\mathrm{VMI}$ & \\
\hline \multirow{3}{*}{3} & 5 & Walking Beads & $\mathrm{L}-\mathrm{VMI}$ & \multirow{3}{*}{$\begin{array}{l}\text { Walking on tiptoes } \\
\text { Walking up the stairs } \\
\text { Walking down the stairs }\end{array}$} \\
\hline & & & & \\
\hline & 6 & Match the Colors & $L-G$ & \\
\hline \multirow[b]{2}{*}{4} & 7 & Let's Walk First Then Jump & $L-G$ & \multirow{2}{*}{$\begin{array}{l}\text { Walking on the line } \\
\text { Jumping forward } \\
\text { Jumping upwards }\end{array}$} \\
\hline & 8 & Jump and Paste on the Wall & $\mathrm{L}-\mathrm{VMI}$ & \\
\hline \multirow{3}{*}{5} & 9 & Hoppy Frog's Forest Trip & $\mathrm{L}$ & \multirow{3}{*}{$\begin{array}{l}\text { Running } \\
\text { Jumping from the obstacle } \\
\text { Jumping down }\end{array}$} \\
\hline & & & & \\
\hline & 10 & Push and Pull & $\mathrm{L}$ & \\
\hline \multirow{3}{*}{6} & 11 & Buttons in My Hands & $\mathrm{G}-\mathrm{VMI}$ & \multirow{3}{*}{$\begin{array}{l}\text { Touching the fingers } \\
\text { Dropping in the bottle } \\
\text { (Un)buttoning buttons }\end{array}$} \\
\hline & & & & \\
\hline & 12 & Sound Buttons & $\mathrm{G}-\mathrm{VMI}$ & \\
\hline \multirow{3}{*}{7} & 13 & Cubes That Changing Shapes & $\mathrm{VMI}-\mathrm{G}$ & \multirow{3}{*}{ Building with cubes } \\
\hline & & & & \\
\hline & 14 & Building My Own Construction & $\mathrm{VMI}-\mathrm{G}$ & \\
\hline
\end{tabular}


Table 1. MDSP-C activities (continued)

\begin{tabular}{|c|c|c|c|c|}
\hline Week & $\mathrm{Nar}$ & e of the Activity & Motor Development Area & Movement Skills \\
\hline \multirow[b]{2}{*}{8} & 15 & Octopus Arms & VMI & \multirow{2}{*}{$\begin{array}{l}\text { Cutting paper } \\
\text { Stringing beads } \\
\text { Lacing string }\end{array}$} \\
\hline & 16 & Colorful Beads & $\mathrm{VMI}-\mathrm{S}$ & \\
\hline \multirow{2}{*}{9} & 17 & Drawing Lines & VMI - S & \multirow{2}{*}{ Using a marker } \\
\hline & 18 & Making Dough Shapes & VMI & \\
\hline \multirow{2}{*}{10} & 19 & Moving Balls & $\mathrm{OM}-\mathrm{VMI}$ & \multirow{2}{*}{$\begin{array}{l}\text { Throwing ball-overhand } \\
\text { Throwing ball-underhand }\end{array}$} \\
\hline & 20 & Tilting the Bowling Pins & $\mathrm{OM}-\mathrm{S}$ & \\
\hline \multirow{2}{*}{11} & 21 & Your Ball, My Ball & $\mathrm{OM}-\mathrm{L}$ & \multirow{2}{*}{$\begin{array}{l}\text { Catching the ball } \\
\text { Kicking the ball }\end{array}$} \\
\hline & 22 & Ball on the String & $\mathrm{OM}-\mathrm{S}$ & \\
\hline \multirow{2}{*}{12} & 23 & Hitting the Balls to the Target & $\mathrm{OM}$ & \multirow{2}{*}{$\begin{array}{l}\text { Hitting the target } \\
\text { Bouncing the ball }\end{array}$} \\
\hline & 24 & Balls in the Basket & $\mathrm{OM}$ & \\
\hline
\end{tabular}

S: Stationary, L: Locomotion, OM: Object manipulation, G: Grasping, VMI: Visual-motor integration

When Table 1 is examined, it is seen that the activities applied twice a week were balanced in such a way to support the skills that support gross and fine motor development. The two activities of the first week were planned as introductory activities. Therefore, no specific motor skill was identified for these two activities. In the other weeks following the first week, certain motor skills such as stationary, locomotion, object manipulation, grasping and visual-motor integration were applied in two different activities each week. In addition, within the scope of the spiral structure of the national preschool education program (Turkish Ministry of National Education, 2013a), acquisitions and indicators have been reevaluated by means of a variety of activities when necessary.

\section{Creation of Motor Development Support Program for Mothers (MDSP-M)}

MDSP-M was developed to raise awareness of mothers on motor development of 36-47 monthold children, to give them an idea about what kind of environment they can prepare for the motor development of their children, and to provide activity ideas that will help them comfortably support motor development of their children at home and it is an institution and home-centered family training program applied to experimental group-II. This program, that aims at integrating the education that the children of the mothers who are the audience of MDSP-M receive from preschool institutions, the information that the mothers grasped within the program, the activities that they carry out to support their children's development inside thehouse and the home visit activities, has been designed in accordance with Bronfenbrenner's bioecological systems theory 
that emphasizes the speculative extend of the program and the relationship between the institution (school) and the house (Bronfenbrenner \& Morris, 2006).

The program was conducted as weekly group meetings, home activities and home visits. MDSP-M consists of a total of 14 sessions to be applied on a weekly basis for 12 weeks (two times in the first and the last weeks). The duration of each session was planned to be 90 minutes. Play-based activities are included in MDSP-M in order to provide mother with the oppurtunity to support their children's motor development in the most correct way and to bring mothers together with the activities appropriate for the age and developmental characteristics of their children. For this purpose, the applications made with children in MDSP-C were taken as basis for the applications made for the mothers in the program. The purpose here is to ensure that the support programs are handled with integrity by showing the applications made with children by the researcher to the mothers so they can do these activities with their children. Because Kagitcibasi, Sunar, and Bekman (2001) stated that the most effective support programs are the programs that put the child in the center and provide training and support to both the child and the family. Therefore, using the content of MDSP-C, applied directly to children by the research, also for the MDSP-M showed that MDSP-C was applied indirectly to the children of mothers in experimental group-II.

Two sessions were held in the first week of the program. In the sessions, warming activities were applied to meet the group, information was given about the purpose and content of the program and theoretical information (motor development, motor development areas, factors affecting motor development, motor development according to age, role of the family in supporting the motor development of the child) were explained to the mothers. In the following eleven sessions, except for the last session, there were two educational activities (two weekly activities of MDSPC) related to the movement skills that mothers can apply/adapt with their children and also information was given about the relationship between skills and daily life. In the sessions, after the first educational activity, there were studies about which movement skills are involved in the activity and about the mothers' ability to exhibit these skills in their children's daily life, and after the second educational activity, studies on mothers to create different activities for their children by using movement skills were included. The mothers practiced the related skills with their children until the next session. In order to transfer the movement skills by the mothers to the child correctly and appropriately, after the movements were done gradually by the researcher, the mothers applied the ones shown. Afterwards, visuals and application details of the skills were distributed to the mothers in written form. In the last session of the last week, a general evaluation was made. 
Within the scope of the MDSP-M, home visits were organized by the researcher. In the home visits; it is aimed to inform the mothers in order to support the child's motor development in the most correct way, to offer suggestions to the mothers about how the home environment can be used as a learning environment in which the child can exhibit their movement skills, to model how to show some movement skills to the child first and then how to practice the shown skill together with the child.

\section{Data Collection Process}

With the help of application form explaining the purpose and content of the study, utilization permit of PDMS-2 was obtained. For ethical aspects of the research, Directorate of Ethical Committee from Ankara University was consulted, and ethical approval was obtained with decree no. and date of 24/03/2016-8/110. Also, Ankara Provincial Directorate of National Education was consulted in order to get necessary permission for validity and reliability study of the scale, and approval was taken with decree no. and date of 06/10/2016-10893844.

Before the application of instructional programs, researcher participated in various activities carried out in the classes in order to get familiar with the children who are in experimental and control groups in the opening week of the school. Afterwards, PDMS-2 was applied as a pretest on the children who are in experimental group-I and control group, and also on the children whose mothers are in experimental group-II in order to identify the children's motor development levels.

After the completion of pretests, MDSP-C and MDSP-M that were planned as 12-week programs applied in 10 weeks. A change in the application process was caused by lack of time for posttests at the end of the semester. When we take into account that pretests took 3 weeks to be completed and there was not enough time for posttests to be completed after having 12-week programs beginning from October 16, 2017; and also, considering the decrease in the attendance in the last week of the semester and the approaching semester break after January 19, 2018, it was decided to adapt the application process based on mentioned reasons. Since both programs were shortened in 10 weeks, activities planned for those 2 weeks added into the plan of the other weeks.

After the completion of MDSP-C and MDSP-M, PDMS-2 was applied as a posttest on the children who are in experimental group-I and control group, and also on the children whose mothers are in experimental group-II. After the posttest applications, about a month later, PDMS-2 was reapplied on the children who are in experimental group-I and on the children whose mothers are in experimental group-II in order to evaluate the retention of the programs. 


\section{Statistical Analysis}

The analysis were made by using the raw scores obtained from PDMS-2. It was tested whether or not the pretest, posttest, and retention test score distributions obtained from the gross and fine motor quotients of PDMS-2 and their subtests of experimental group-I, experimental group-II and control group were compatible with normality and homogeneity assumptions. For the normality assumption, skewness/standard error and kurtosis/standard error values were examined and it was identified that the coefficients were between \pm 1.96 . Can (2014) stated that distribution is normal in case values obtained are between \pm 1.96 . Therefore, the pretest, posttest, and retention test scores of the groups showed normal distribution. The Levene's test was conducted to test the homogeneity assumption. It was concluded as a result of the test that there was no significant difference between the variances of the scores ( $\mathrm{p}>.05)$. One-way ANOVA analysis was applied to determine whether or not the children in the groups had similar characteristics before the experimental procedures. As a result of the analysis, it was found that the pretest scores obtained from the gross motor and fine motor quotients with subtests did not show a statistically significant difference compared to the groups ( $\mathrm{p}>.05)$. This result revealed that the experimental-I, experimental-II and control groups were similar in the initiation stage of the experimental study.

Two-way ANOVA analysis was used for mixed patterns that can address between-group, withingroup and common effect together in order to determine the effect of experimental process. However, the analysis results may not be sufficient alone about the effectiveness of the experimental procedure. Therefore, Post Hoc (LSD) Test for the comparisons among experimental group-I, experimental group-II and control group and one-way ANOVA analysis was applied for the difference scores between the pretest and posttest scores. In addition, the retention test (oneway ANOVA for repeated measures) was applied in order to determine the retention of the effect of experimental procedure for the children only in experimental group-I and experimental groupII.

\section{RESULTS}

Tables 2, 3, and 4 show the results on the comparison of experimental group-I, experimental groupII and control group for the stationary subtest of the gross motor quotient. 
Table 2. Stationary: Two-way ANOVA results for mixed patterns of pretest and posttest scores

\begin{tabular}{lrrrrr}
\hline Source of Variance & \multicolumn{1}{c}{ SS } & df & MS & F & P \\
\hline Between-group & 313.77 & 34 & & & \\
\hline Group $\left(\mathrm{E}_{1} . \mathrm{E}_{2} . \mathrm{C}\right)$ & 3.47 & 2 & 1.73 & 0.18 & .84 \\
\hline Error & 310.30 & 32 & 9.69 & & \\
\hline Within-group & 115.98 & 35 & & & $.00^{*}$ \\
\hline Measurement (Pretest-Posttest) & 107.58 & 1 & 50.14 & 50.14 & $.02^{*}$ \\
\hline Group*Measurement & 17.68 & 2 & 8.84 & 4.12 & \\
\hline Error & 68.65 & 32 & 2.14 & & \\
\hline Total & 338.46 & 69 & & & \\
\hline
\end{tabular}

When Table 2 was examined, the group effect (experimental-I, experimental-II and control) was not statistically significant $(\mathrm{p}>.05)$. This result showed that the stationary subtest scores of the children did not differ between the groups without making pretest and posttest discrimination. When the measurement (pretest-posttest) effect was taken into consideration, a statistically significant difference was obtained between the pretest and posttest mean scores of the children $[F(1,32)=50.14 ; \mathrm{p}<.05]$. According to this obtained result, it can be said that all children changed significantly according to the measurements of stationary subtest scores without group discrimination. When considering the common effect of the group*measurement made to determine the effectiveness of the applied experimental procedure, it is concluded that although it was in different procedure groups, the common effects of repeated measurement factors on the stationary subtest scores of children were statistically significant $[F(2,32)=4.12 ; p=.02]$. However, this result may not be sufficient alone on the effectiveness of the experimental procedure. Therefore, Post Hoc Test was used for comparisons between pretest and posttest scores of the experimental group-I, experimental group-II, and control group and the results are presented in Table 3.

Table 3. Stationary: Post Hoc Test results for pretest and posttest scores

\begin{tabular}{|c|c|c|c|c|c|}
\hline Group & Measurement & $\overline{\mathrm{X}}$ & Std. Error & Posttest and Pretest Difference & $\mathrm{p}$ \\
\hline \multirow[b]{2}{*}{$\mathrm{E}_{1}$} & Pretest & 4.92 & 0.63 & \multirow{2}{*}{3.00} & \multirow{2}{*}{$.00^{\circ}$} \\
\hline & Posttest & 7.92 & 0.71 & & \\
\hline \multirow{2}{*}{$\mathrm{E}_{2}$} & Pretest & 4.30 & 0.72 & \multirow{2}{*}{3.40} & \multirow{2}{*}{$.00^{\circ}$} \\
\hline & Posttest & 7.70 & 0.81 & & \\
\hline \multirow{2}{*}{$\mathrm{C}$} & Pretest & 6.00 & 0.66 & \multirow{2}{*}{1.08} & \multirow{2}{*}{.08} \\
\hline & Posttest & 7.08 & 0.74 & & \\
\hline
\end{tabular}

When the paired comparisons for the pretest and posttest scores of the stationary subtest of the groups were examined in Table 3, it was observed that the pretest and posttest scores of the children in experimental group-I and experimental group-II differed statistically significantly $(\mathrm{p}<.05)$. However, the same situation is not the case for the control group. Similarly, ANOVA Test was used to determine whether the difference between the posttest and pretest scores differed by groups and the results are presented in Table 4. 
Table 4. Stationary: ANOVA Test results for pretest and posttest difference scores

\begin{tabular}{|c|c|c|c|c|c|c|}
\hline Group & SS & $\mathrm{df}$ & MS & $\mathrm{F}$ & $p$ & Difference \\
\hline Between-group & 35.37 & 2 & 17.69 & \multirow{3}{*}{4.12} & \multirow{3}{*}{.03} & \multirow{3}{*}{$\begin{array}{l}E_{1}>C \\
E_{2}>C\end{array}$} \\
\hline Within-group & 137.32 & 32 & 4.29 & & & \\
\hline Total & 172.69 & 34 & & & & \\
\hline
\end{tabular}

When Table 4 was examined, it was determined that difference scores of the children from the stationary subtest scores showed a statistically significant difference in terms of the groups $[\mathrm{F}(2$, $34)=4.12 ; p=.03]$. As a result of the Post Hoc Test conducted to determine the source of the difference, the reason for the statistical difference shown by the difference scores obtained from posttest and pretest scores in terms of the groups was found to be between experimental group-I and control group in favor of experimental group-I and between experimental group-II and control group in favor of experimental group-II. In other words, while the difference scores of the children obtained from the posttest and pretest showed difference between experimental group-I and control group and between the experimental group-II and control group, they did not differ between experimental group-I and experimental group-II. Therefore, when the results obtained from Table 3 and Table 4 were examined together, it can be asserted that the score increase of the children occurred in the stationary subtests in the experimental groups I and II was caused by the experimental procedures; however, the experimental procedures did not give any advantage over one another.

In the analysis conducted to determine the retention of the experimental procedures' effects, it was determined that there was a statistically significant difference between the stationary subtest pretest, posttest and retention test scores of experimental group-I $[\mathrm{F}(1.09,13.03)=24.79 ; \mathrm{p}<.05]$ and experimental group-II $[\mathrm{F}(1.19,10.75)=32.52 ; \mathrm{p}<.05]$. As a result of the pair comparisons made to determine the cause of the difference for experimental group-I, the difference between the posttest $(\overline{\mathrm{X}}=7.92)$ and pretest $(\overline{\mathrm{X}}=4.92)$ and between retention test $(\overline{\mathrm{X}}=8.15)$ and pretest scores $(\overline{\mathrm{X}}=4.92)$ was found to be significant; however, the difference between the posttest and retention test scores was not significant. As a result of the pair comparison conducted to determine the cause of the difference for experimental group-II, it was found that the difference between the posttest $(\overline{\mathrm{X}}=$ 7.70) and pretest $(\overline{\mathrm{X}}=4.30)$ and between retention test $(\overline{\mathrm{X}}=8.10)$ and pretest scores $(\overline{\mathrm{X}}=4.30)$ was significant while the difference between the posttest and the retention test scores was not significant. These results show that the scores of the stationary subtest increased significantly in the posttest and retention test measurements compared to pretest measurements but the posttest scores did not differ from the retention scores. 
Tables 5, 6, and 7 show the results of the gross motor quotient in the comparison of the experimental group-I, experimental group-II, and the control group.

Table 5. Gross motor: Two-way ANOVA results for mixed patterns of pretest and posttest scores

\begin{tabular}{lrrrrr}
\hline Source of Variance & SS & df & MS & F & P \\
\hline Between-group & 6366.33 & 34 & & & \\
\hline Group $\left(\mathrm{E}_{1} . \mathrm{E}_{2} . \mathrm{C}\right)$ & 152.98 & 2 & 76.49 & 0.39 & .68 \\
\hline Error & 6213.35 & 32 & 194.17 & & \\
\hline Within-group & 3579.26 & 35 & & & $.00^{*}$ \\
\hline Measurement (Pretest-Posttest) & 2890.12 & 1 & 2890.12 & 202.34 & $.01^{*}$ \\
\hline Group*Measurement & 142.08 & 2 & 71.04 & 4.97 & \\
\hline Error & 547.06 & 32 & 14.28 & & \\
\hline Total & 9945.59 & 69 & & & \\
\hline
\end{tabular}

When Table 5 was examined, the group (experimental-I, experimental-II, and control) effect was not statistically significant ( $\mathrm{p}>.05$ ). This result showed that the gross motor quotient scores did not differ between groups without the pretest and posttest discrimination. When the measurement effect (pretest-posttest) was considered, a statistically significant difference was obtained between the pretest and posttest mean scores of the children $[\mathrm{F}(1,32)=202.34 ; \mathrm{p}<.05]$. According to the result, it can be asserted that the gross motor quotient scores of all children changed significantly according to the measurements without any group discrimination. When considering the common effect of the group*measurement conducted to determine the effectiveness of the experimental procedure, it was determined that common effects of the repeated measurement factors on the gross motor quotient scores of the participants were statistically significant, although they were in the different groups $[\mathrm{F}(2,32)=4.97 ; \mathrm{p}=.01]$. However, this result alone may not be sufficient on the effectiveness of the experimental procedure. Therefore, the Post Hoc Test was used for comparisons among experimental group-I, experimental group-II and control group and the results are presented in Table 6.

Table 6. Gross motor: Post Hoc Test results for pretest and posttest scores

\begin{tabular}{|c|c|c|c|c|c|}
\hline Group & Measurement & $\overline{\mathrm{X}}$ & Std. Error & Posttest and Pretest Difference & $\mathrm{p}$ \\
\hline \multirow{2}{*}{$\mathrm{E}_{1}$} & Pretest & 31.69 & 2.90 & \multirow{2}{*}{14.77} & \multirow{2}{*}{$.00^{*}$} \\
\hline & Posttest & 46.46 & 2.76 & & \\
\hline \multirow{2}{*}{$\mathrm{E}_{2}$} & Pretest & 32.80 & 3.30 & \multirow{2}{*}{15.10} & \multirow{2}{*}{$.00^{*}$} \\
\hline & Posttest & 47.90 & 3.15 & & \\
\hline \multirow{2}{*}{$\mathrm{C}$} & Pretest & 32.25 & 3.01 & \multirow{2}{*}{8.92} & \multirow{2}{*}{$.00^{*}$} \\
\hline & Posttest & 41.17 & 2.88 & & \\
\hline
\end{tabular}

When the pair comparisons on the pretest and posttest scores of the groups in the gross motor quotient were examined in Table 6 , the pretest and posttest scores of the children in experimental group-I, experimental group-II, and control group differed statistically significantly $(\mathrm{p}<.05)$. 
Similarly, ANOVA Test was used to determine whether the difference between the posttest and pretest scores differed by groups and the results are presented in Table 7.

Table 7. Gross motor: ANOVA Test results for pretest and posttest difference scores

\begin{tabular}{|c|c|c|c|c|c|c|}
\hline Group & SS & $\mathrm{df}$ & MS & $\mathrm{F}$ & $\mathrm{p}$ & Difference \\
\hline Between-group & 284.16 & 2 & 142.08 & \multirow{3}{*}{4.97} & \multirow{3}{*}{.01} & \multirow{3}{*}{$\begin{array}{l}E_{1}>C \\
E_{2}>C\end{array}$} \\
\hline Within-group & 914.12 & 32 & 28.57 & & & \\
\hline Total & 1198.29 & 34 & & & & \\
\hline
\end{tabular}

When Table 7 was examined, it was determined that the difference scores of the children for the gross motor quotient showed a statistically significant difference according to the groups $[\mathrm{F}(2$, $34)=4.97 ; p=.01]$. As a result of the Post Hoc Test conducted to determine the cause of the difference, it was found that the cause of the statistical difference shown by the difference scores obtained from the posttest and pretest scores was between experimental group-I and control group in favor of experimental group-I and between experimental group-II and control groups in favor of experimental group-II. In other words, while the difference scores of the children from the posttest and pretest varied between experimental group-I and control group and between experimental group-II and control group, they did not show any difference between the experimental groups I and II. Therefore, when the results obtained from Table 6 and Table 7 were considered together, it can be asserted that the score increase in the gross motor quotient of children in the experimental groups I and II was caused by the experimental procedures but the experimental procedures did not provide any advantage to one another.

In the analysis conducted to determine the retention of the effect of the experimental procedures, a statistically significant difference was determined among the pretest, posttest, and retention test scores of experimental group-I $[\mathrm{F}(2,24)=152.85 ; \mathrm{p}<.05]$ and experimental group-II $[\mathrm{F}(1.10$, $9.92)=51.30 ; \mathrm{p}<.05]$ in the gross motor quotient. As a result of the pair comparisons conducted to determine the cause of the difference for experimental group-I, the difference between posttest $(\bar{X}=46.46)$ and pretest $(\bar{X}=31.69)$, between retention test $(\bar{X}=48.92)$ and pretest scores $(\bar{X}=31.69)$ and between retention test $(\bar{X}=48.92)$ and posttest $(\bar{X}=46.46)$ scores was determined to be significant. As a result of the pair comparisons conducted to determine the cause of the difference for experimental group-II, the difference between posttest $(\overline{\mathrm{X}}=47.90)$ and pretest $(\overline{\mathrm{X}}=32.80)$, between retention test $(\bar{X}=50.60)$ and pretest scores $(\bar{X}=32.80)$ and between retention test $(\overline{\mathrm{X}}=$ 50.60) and posttest $(\bar{X}=47.90)$ scores was determined to be significant. These results showed that the scores of the gross motor quotient increased significantly in the posttest and retention test measurements compared to the pretest measurements; similarly, the retention test scores differed from the posttest scores. 
In the study, the effect of the experimental procedure on the locomotion and object manipulation subtests of the PDMS-2 gross motor quotient and on the fine motor quotient and the grasping and visual-motor integration subscales of this quotient were also examined. When the pretest and posttest scores obtained as a result of the analysis were examined, no statistically significant difference ( $p>.05)$ was found between the pretest and posttest scores of the children in experimental group-I, experimental group-II and the control group. Therefore, it was found that the experimental procedure was not effective, that is, MDSP-C and MDSP-M had no effect in increasing the locomotion, object manipulation, grasping, visual-motor integration and fine motor scores of the children.

\section{DISCUSSION and CONCLUSION}

It was determined that the score increase occurring in the stationary subtest of the children in the experimental groups I and II was caused by the experimental procedures. It has been concluded in different studies that the programs applied to the preschool children (Bellows, Davies, Anderson, \& Kennedy, 2013; Boz, 2011; Mülazımoğlu Ballı, 2006), have an effect on the stationary skills. In their study, Ruiz-Esteban, Terry Andrés, Méndez, and Morales (2020) concluded that the gross motor intervention program implicitly effected the children's balance performances and caused increase. The stationary (static and dynamic), which is the basis of all movements, is the ability of a person to maintain his/her location even if he/she has different positions (Gallahue, Ozmun, \& Goodway, 2012). Since PDMS-2 used in the study focuses on the skills of standing on one foot and at the fingertip of 36-47 month-old children in the stationary subtest, it is possible to evaluate the stationary subtest within the static stationary. According to Lam, Ip, Lui, and Koong (2003), static stationary progresses with age after four years of age. When both this study and the studies supporting the stationary skills of the children are examined, it is seen that the children forming the sample group are aged between 3 and 6 years. Therefore, in accordance with the results of the study, it can be asserted that the age of the sample group was in parallel with the age-related development of the static stationary expressed in the literature.

In addition, it was determined that the score increase in the children in the experimental groups I and II in the gross motor quotient was also caused by the experimental procedures. It was concluded in the literature that the programs applied to the preschool children were effective on the gross motor development of children (Bellows et al., 2013; Boz \& Güngör Aytar, 2012; Mülazımoğlu Ball, 2006; Wang, 2004). Palmer, Chinn, and Robinson (2019) conducted a motor activity program on a group consisting of male and female children at the end of which an increase 
was witnessed in the motor development performance of the relevant male and female children. Likewise, another study showed that the children in an experimental group where a program developed at the end of an intervention program for 36-48 month old children was conducted showed better performance compared to the children in the control group where they carry out free activities (Ruiz-Esteban et al., 2020). In the study, posttest scores were determined to be higher compared to the pretest scores in the control group. Yildirim, Bilge, and Caglar (2019) concluded that pretest and posttest results created a difference in all the groups within the scope of the study, that is to say the intervention process of the posttest scores of the children in the control group showed an increase as well. The effect of maturation in the gross motor development of children can be mentioned on the score increase in all groups regardless of whether or not applying motor development supportive programs (Haibach, Reid, \& Collier, 2011; Payne \& Isaacs, 2012). However, it was seen that the score increase in the skills in favor of the experimental groups was caused by the motor development support programs applied to the children and mothers. MDSP$\mathrm{C}$ and MDSP-M were prepared within the study to support the stationary, locomotion and object manipulation skills. Folio and Fewell (2000) stated that although the stationary, locomotion and object manipulation skills provided an idea about the motor skills of each child, gross motor quotient gave better results since gross motor covers all three skills and represents many skills. Although MDSP-C and MDSP-M made a difference only in the stationary skills among the subtests but did not make any difference in the other two subtests (locomotion and object manipulation), it reveals that these programs making a difference in the gross motor quotient covering all three skills in favor of the experimental groups can be effective in supporting the gross motor development of children.

Although it was determined that the score increase both in the stationary subtest and gross motor quotient was caused by the experimental procedures, experimental procedures were concluded not to provide any advantage over each other. This is thought to be due to the fact that the play-based MDSP-C and MDSP-M content were the same and the children had similar characteristics.

In the study, although the posttest scores obtained by the children in the experimental groups from the fine motor quotient and grasping and visual-motor integration subtests forming this quotient after MDSP-C and MDSP-M were higher than the pretest scores, there was no significant difference between the pretest and posttest scores. Therefore, MDSP-C and MDSP-M prepared to support the fine motor skills of children were observed not to have any effect in increasing the fine motor scores of the children. It is expressed that the preschool children gain control over many fine motor skills such as throwing small objects into the box, buttoning/unbuttoning, beading, 
passing the string through the hole, building towers, bridge, wall, and stair structures from cubes (SSahin, 2017). However, the skill of holding the pencil properly used for writing activities is gained at the beginning of primary school since the finger muscles are not fully developed in the preschool period (Bee \& Boyd, 2010; Polat, 2013). Therefore, fine motor skills show improvement as the age increases, i.e. depending on the maturation (Düger, Bumin, Uyanık, Ak1, \& Kayıhan, 1999). The studies ascertaining the relationship of fine motor skills with the age show that children master in fine motor skills as they age (Dourou, Komessariou, Riga, \& Lavidas, 2017; Manna, Pal, \& Dhara, 2018). Although the effect of the maturation exists in the fine motor development, increasing the quality of the fine motor skills is also closely associated with applying more practices and experiencing through repetitions by the children. Mağden, Şahin, Baç Karaaslan, and Işıtan (2004) indicated that more opportunities should be given to preschool children in the skills about the development of small muscle motor development. In their research investigating the effects of the preschool fine motor skills on the future academic processes, Escolano-Pérez, Herrero-Nivela, and Losada (2020) concluded that the academic skills of children with low fine motor skills were effected. Besides, researchers argued that the early evaluation of fine motor skills could be crucial in terms of identifying the children with a potential of demonstrating low performance and emphasized the importance of the intervention programs. Thanks to the planned and long-term training activities, it can be more possible to support the motor development of children. Therefore, when the time of the experimental process conducted to support the motor development of 36-47 month-old children was considered, it is possible to assert that the difference between them can increase to significant levels by preparing the motor development support programs to cover one year and increasing the working time.

In the analysis conducted to determine the retention of the experimental procedures, it can be said that the increase in the retention test scores may be due to the maturation that is effective in the improvement of both gross motor and fine motor skills depending on conducting the retention test application approximately one month after the posttest, that is, due to the advancement of the children's ages. It was determined in the study by Tepeli (2007) that children were more successful in their movement skills with the increase in age. In addition, the fact that the families of the children in experimental group-I and the mothers of the children in experimental group-II continued the activities at home presented in the family involvement studies to support the motor developments of the children during the semester holiday elapsing from the posttest to retention test may have made contribution to the continuity of the effect of the programs. It is expressed in the literature that the participation of the families to the education given to the preschool children is effective in the success of the child and the retention of the success is possible by supporting 
and maintaining the education at home (Turkish Ministry of National Education, 2013b; Temel, 2008) and also the other researches reflect that the stimulating environment created at home has an important role in children's motor development (Ferreira, Godinez, Gabbard, Vieira, \& Caçola, 2018).

Experimental design was used in this study examining the effectiveness of motor development support programs on supporting the motor development of 36-47 month-old children. In different studies to be conducted to determine the effect of motor development support programs on the motor development of children, the reliability of the research can be increased by not only using experimental design but also qualitative research techniques. In the study, motor development support program was applied to the 36-47 month-old children and to the mothers with children in this age group. In different studies to be conducted, the effectiveness of the education can be increased by providing education for both 36-47 month-old children and their mothers together.

In this study, there are some limitations. One of the limitations is that age of children was limited to 36-47 month in the study group. In future studies, by developing motor development support programs to support the motor development of children from different age groups in preschool period, their effectiveness can be investigated. In addition, the small number of the sample group constitutes a limitation. In future studies, by selecting various early childhood education institutions consisting 36-47 month-age children, number of participants in the study group can be higher and generalizability of the findings can be increased. Another limitation of the study is that study group consisted of only children who demonstrate age-expected development. Since PDMS-2 can be used for both children with age-expected development and children with special needs, children with special needs can be consisted in the study groups in future studies.

\section{REFERENCES}

Anna, M., Glykeria-Erato, P., Aspasia, D., \& Fotini, V. (2016). Effect of a psychomotor program on the motor proficiency and self-perceptions of preschool children. Journal of Physical Education and Sport, 16(4). 1365-1371. doi:10.7752/jpes.2016.04218

Bee, H., \& Boyd, D. (2010). The developing child (12. ed.). Boston, MA: Allyn \& Bacon.

Bellows, L. L., Davies, P. L., Anderson, J., \& Kennedy C. (2013). Effectiveness of a physical activity intervention for Head Start preschoolers: A randomized intervention study. The American Journal of Occupational Therapy, 67(1), 28-36. doi:10.5014/ajot.2013.005777

Boonzaaijer, M., van Wesel, F., Nuysink, J., Volman, M. J. M., \& Jongmans, M. J. (2019). A homevideo method to assess infant gross motor development: Parent perspectives on feasibility. BMC Pediatrics, 19. doi:10.1186/s12887-019-1779-x 
Boz, M. (2011). The effect of the fundamental movement education program, which is performed on 5-6 year old children, on movement skills (Unpublished doctoral dissertation). Gazi University, Ankara.

Boz, M., \& Güngör Aytar, A. (2012). The effects of the fundamental movement education on preschool children's movement skills [Special issue]. Hacettepe University Journal of Education, $1,51-59$.

Bronfenbrenner, U., \& Morris, P. A. (2006). The bioecological model of human development. In W. Damon, \& R. M. Lerner (Eds.), Handbook of Child Psychology: Theoretical Models of Human Development (6th ed.) (pp. 793-828). Hoboken, NJ: John Wiley \& Sons.

Büyüktaşkapu, S. (2012). An investigation of the relationship between mothers' perception of self efficacy and development of their children aged between 1 and 3. Amasya Education Journal, 1(1), 18-30.

Can, A. (2014). SPSS ile Bilimsel Arasttrma Sürecinde Nicel Veri Analizi (3rd ed.). Ankara: Pegem Akademi.

Cauldfield, R. A. (2000). Infants and Toddlers. Upper Saddle River, NJ: Pearson Education.

Düger, T., Bumin, G., Uyanık, M., Akı, E., \& Kayıhan, H. (1999). The assessment of BruininksOseretsky Test of motor proficiency in children. Pediatric Rehabilitation, 3(3), 125-131.

Dourou, E., Komessariou, A., Riga, V., \& Lavidas, K. (2017). Assessment of gross and fine motor skills in preschool children using the Peabody Developmental Motor Scales Instrument. European Psychomotricity Journal, 9(1), 89-113.

Escolano-Pérez, E., Herrero-Nivela, M. L., \& Losada, J. L. (2020). Association between preschoolers' specific fine (but not gross) motor skills and later academic competencies: Educational implications. Frontiers in Psychology, 11. doi:10.3389/fpsyg.2020.01044

Ferreira, L., Godinez, I., Gabbard, C., Vieira, J. L. L., \& Caçola, P. (2018). Motor development in school-age children is associated with the home environment including socioeconomic status. Child: Care, Health and Development, 44(6), 801-806. doi:10.1111/cch.12606

Folio, M. R., \& Fewell, R. R. (2000). Peabody Developmental Motor Scales (2nd ed.). Austin, TX: PROED.

Gallahue, D. L., Ozmun, J. C., \& Goodway, J. D. (2012). Understanding Motor Development: Infants, Children, Adolescents, Adults (7th ed.). New York, NY: McGraw-Hill.

Haibach, P. S., Reid, G., \& Collier, D. H. (2011). Motor Learning and Development. Champaign, IL: Human Kinetics.

Haktanır, G., \& Aktaş, Y. (1995). 3-4 yaş çocuklarının motor gelişim özelliklerinin incelenmesi. 10th Ya-Pa Preschool Education and Widespreading Seminar (pp. 139-148), Ankara.

Hamilton, M., Goodway, J., \& Haubenstricker, J. (1999). Parent-assisted instruction in a motor skill program for at-risk preschool children. Adapted Physical Activity Quarterly, 16(4), 415-426. doi:10.1123/apaq.16.4.415 
Haywood, K. M., Roberton, M. A., \& Getchell, N. (2012). Advanced Analysis of Motor Development. Champaign, IL: Human Kinetics.

Hurmeric, I. (2010). The effects of two motor skill interventions on preschool children's object control skills and theirperceived motor competence (Unpublished doctoral dissertation). The Ohio State University, Ohio.

Hürmeriç Altunsöz, I. (2015). Motor skill interventions for young children. Niğde University Journal of Physical Education And Sport Sciences, 9(1), 133-148.

Kavousipor, S., Rassafiani, M., Gabbard, C., Pourahmad, S., Hosseini, S. A., Soleimani, F., \& Ebadi, A. (2020). Influence of the home affordances on motor skills in 3- to 18-month-old Iranian children. Early Cbild Development and Care. doi:10.1080/03004430.2020.1727463

Kagitcibasi, C., Sunar, D., \& Bekman S. (2001). Long-term effects of early intervention: Turkish low-income mothers and children. Applied Developmental Psychology, 22, 333-361. doi:10.1016/S0193-3973(01)00071-5

Kalıpçı Söyler, S. (2019). The effects of fine motor education program on fine motor skills, school readiness levels and self-regulation skills of children attending preschool (Unpublished doctoral dissertation). Pamukkale University, Denizli.

Lam, M. Y., Ip, M. H., Lui, P. K., \& Koong, M. K. (2003) How teachers can assess kindergarten children's motor performance in Hong Kong. Early Child Development and Care, 173(1), 109118. doi:10.1080/0300443022000022468

Mağden, D., Şahin, S., Baç Karaaslan, T., \& Işıtan, S. (2004). Assessment of fine and gross motor development skill levels of three-six years old children in Ankara. Journal of Child Development and Education, 1(10-11), 23-36.

Manna, S., Pal, A., \& Dhara, P. C. (2018). Fine motor skills and its growth pattern in variation to age and gender on Bengali (Indian) primary school children: A cross sectional study. International Journal of Health Sciences and Research, 8(5), 51-61.

Mülazımoğlu Ballı, Ö. (2006). The study of validity and reliability of Bruininks-Oseretsky Motor Proficiency Test and the effects of gymnastics education program on motor development of five-six-years-old children (Unpublished doctoral dissertation). Ankara University, Ankara.

Palmer, K. K., Chinn, K. M., \& Robinson, L. E. (2019). The effect of the CHAMP intervention on fundamental motor skills and outdoor physical activity in preschoolers. Journal of Sport and Health Science, 8(2), 98-105. doi:10.1016/j.jshs.2018.12.003

Payne, V. G., \& Isaacs, L. D. (2012). Human Motor Development: A Lifespan Approach (8th ed.). New York, NY: McGraw-Hill.

Polat, Ö. (2013). Okul öncesi eğitim programlarında ilköğretime hazırlık. In A. Oktay (Ed.), İlkögretime Hazırlk ve İlkögretim Programlar (2nd ed.) (pp. 65-86). Ankara: Pegem Akademi.

Qi, Y., Tan, S., Sui, M., \& Wang, J. (2018). Supervised physical training improves fine motor skills of 5-year-old children. Rev Bras Med Esporte, 24(1), 9-12. doi:10.1590/1517869220182401177117 
Ruiz-Esteban, C., Terry Andrés, J., Méndez, I., \& Morales, Á. (2020). Analysis of motor intervention program on the development of gross motor skills in preschoolers. International Journal of Environmental Research and Public Health, 17(13). doi:10.3390/ijerph17134891

Silva, S. D., Flôres, F. S., Corrêa, S. L., Cordovil, R., \& Copetti, F. (2017). Mother's perception of children's motor development in Southern Brazil. Perceptual and Motor Skills, 124(1), 72-85. doi:10.1177/0031512516676203

Şahin, S. (2017). Okul öncesi döneminde motor gelişim. In F. Turan \& A. İ. Yükselen (Eds.), Cocuk Gelişimi 2: Okul Öncesi Döneminde Gelişim (4th ed.) (pp. 23-35). Ankara: Hedef CS.

Taştepe, T., \& Köksal Akyol, A. (2019). The adaptation study of Peabody Developmental Motor Scales-2 for 36-47 month-old children and the investigation of their motor development. Milli Ë̆itim, 48(223), 61-82.

Temel, Z. F. (2008). Okul öncesi eğitimde aile katılımı. International Conference of Preschool Education in the Context of Child, Family and School (pp. 89-98), Trabzon.

Temel, Z. F., \& Kurtulmuş, Z. (2016). Anne baba eğitimi. In N. Aral, Ü. Deniz, \& A. Kan (Eds.), Okul Öncesi Öğretmenliği: Alan Bilgisi (2nd ed.) (pp. 691-725). Ankara: Alan Bilgisi Yayınları.

Tepeli, K. (2007). Standardization of Test of Gross Motor Skills for Turkey (Unpublished doctoral dissertation). Selçuk University, Konya.

Turkish Ministry of National Education. (2013a). Okul öncesi eğitim program. Retrieved from http://tegm.meb.gov.tr/dosya/okuloncesi/ooproram.pdf

Turkish Ministry of National Education. (2013b). Okul öncesi eğitim programı ile bütünlestirilmis aile destek eğitim rehberi. Retrieved from http://tegm.meb.gov.tr/dosya/okuloncesi/obader.pdf

Valadi, S., \& Gabbard, C. (2020). The effect of affordances in the home environment on children's fine- and gross motor skills. Early Child Development and Care, 190(8), 1225-1232. doi:10.1080/03004430.2018.1526791

Vidoni, C., Lorenz, D. J., \& Terson de Paleville, D. (2014). Incorporating a movement skill programme into a preschool daily schedule. Early Child Development and Care, 184(8), 12111222. doi:10.1080/03004430.2013.856895

Wang, J. H-T. (2004). A study on gross motor skills of preschool children. Journal of Research in Childhood Education, 19(1), 32-43. doi:10.1080/02568540409595052

Yildirim, D. S., Bilge, M., \& Caglar, E. (2019). Effects of a training program based on longitudinal training of athlete development (LTAD) approach on gross motor skills among 6-8 years old children. European Journal of Physical Education and Sport Science, 5(3), 35-47. doi:10.5281/zenodo.2532778 